\title{
Characterization of Gastrin-Releasing Peptide Immunoreactivity in Distinct Storage Particles in Guinea Pig Myenteric and Torpedo Electromotor Neurones
}

\author{
C. SHAW, $*$ V. P. WHITTAKER $\dagger^{1}$ AND D. V. AGOSTON $\dagger^{2}$ \\ *Institute of Clintcal Science, Department of Medicine \\ The Queen's University of Belfast, Belfast, U.K. \\ and †Arbeitsgruppe Neurochemie, Max-Planck-Institut für biophysikalische Chemie \\ Göttingen, FR Germany
}

Received 5 June 1989

\begin{abstract}
SHAW, C , V P WHITTAKER AND D V AGOSTON Characterization of gastrin-releasing peptide immunoreactivity in distinct storage particles in guinea pig myenteric and Torpedo electromotor neurones PEPTIDES 11(1) 69-74, 1990 -Using high resolution centrifugal density-gradient separation of cytoplasmic extracts of guinea pig myentenc plexus and Torpedo electric tissue, we have succeeded in isolating fractions of storage particles rich in gastrin-releasing peptide (GRP) In extracts of myenteric plexus and gradients derived therefrom, the 10-amino acid GRP peptide (GRP-10) was the sole form present, this was bimodally distributed In the gradients, one peak copurifying with Golgı membranes and apparently consisting of immature storage particles, the other with other synaptophysin-rich neuropeptide-containing particles In extracts of electric organ, a tissue rich in cholinergic electromotor nerve terminals, and gradients derived therefrom, GRP-like immunoreactivity behaved in gel permeation and reversed phase high performance liquid chromatography like the 27 -amino acid peptıde (GRP-27) About half of the immunoreactivity sedimented in the centrnfugal gradient to a region nch in particles containing vasoactive intestinal polypeptide-like immunoreactivity, the remainder was recovered in a very dense region of the gradient containing larger membrane fragments, including synaptosomes The electromotor nerves and cell bodies also contained GRP-27-like immunoreactivity in relatıvely high concentration as did the Torpedo gut It is concluded that this GRP-like peptide is packaged in dense storage particles in the electromotor neurones
\end{abstract}

Myenteric neurones Electromotor neurones GRP VIP Storage particles

GASTRIN-releasing peptide (GRP) is a neuropeptide found inter alia in mammalian intestıne, lungs and brain which exhibits actıve site sequence homology with the amphibian peptıde, bombesin (7). GRP is known to exist in mammalian tissue in two major molecular forms, GRP-27 and GRP-10, the smaller peptide corresponding to the C-termınal decapeptide amide of the larger. GRP and bombesin are now known to belong to a larger family of related peptides [for reviews see $(16,17)$ ]

In the Gottingen laboratory, much use has been made of two model systems, the myentenc plexus-longitudınal muscle (MPLM) preparation of gunea pig ileum (12) and the electromotor system of the elasmobranch fish Torpedo marmorata (an electric ray) (14), for cell-biological studies of neuropeptıdes, especially one, vasoactive intestinal polypeptide (VIP), which is often found to be colocalized with acetylcholıne ( $\mathrm{ACh})$ in cholinergic termınals. Methods have been devised, using centrifugal density gradient fractionation of cytoplasmic extracts of gumea pIg MPLM (8) and Torpedo electric organ $(12,18)$ in zonal rotors, whereby VIPcontainıng storage granules may be separated from ACh-rich synaptic vesicles and storage vesicles containing other neuropeptides $(1,2,4,5)$. From extracts of MPLM, distinct fractions of vesicles storing substance $P$, somatostatin and VIP have been separated (2), but in the purely cholinergic Torpedo electromotor system, storage granules containing VIP-like immunoreactivity have been up to now the only peptide-containing particles to be ssolated (5).

In the study reported here, we have identified and chromatographically characterızed GRP immunoreactive peptides in extracts of guinea pig MPLM and Torpedo electric organs and have subsequently isolated and partially characterized their storage particles.

\footnotetext{
${ }^{1}$ Requests for reprints should be addressed to V P Whittaker, AG Neurochemie, MPI fur biophysıkalısche Chemıe, Postfach 2841, D-3400 Gottıngen, FR Germany

${ }^{2}$ Present address Laboratory of Cell Bıology, Natıonal Institute of Mental Health, Bldg 36, Rm 3A17, Bethesda, MD 20892
} 


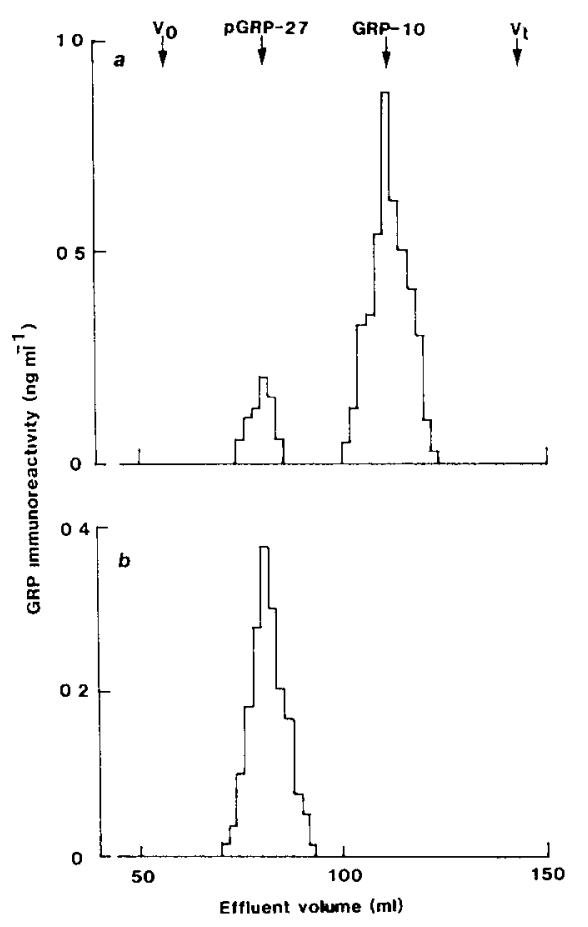

FIG 1 Gel permeation chromatography of acidic extracts of (a) guinea pıg MPLM and (b) Torpedo electnc organ. The columns were calibrated with blue dextran $\left(\mathrm{V}_{\mathrm{o}}\right)$, porcine GRP-27 (pGRP-27) and GRP-10, and potassium dichromate $\left(V_{t}\right)$ as indicated by the arrows Volumes of extract corresponding to about $100 \mathrm{mg}$ of tissue were placed on the columns

\section{METHOD}

\section{Preparation of Cytoplasmic Extracts and Storage of Tissues}

From MPLM preparations. MPLM preparations were made as modified (1) from the original method (2). Briefly, tıssue (8-10 g) from the ilea of 6 guinea pigs of $300-350 \mathrm{~g}$ body weight was homogenized at $4^{\circ} \mathrm{C}$ in 4 volumes of $0.16 \mathrm{M} \mathrm{NaCl}$ containing 10 $\mathrm{mM} 2-\left(N\right.$-2-hydroxyethyl-piperazine- $N^{\prime}$-yl) ethane sulphonate (Hepes) buffer, pH 6.8, $1 \mathrm{mM}$ EGTA, $0.1 \mathrm{mM}$ EDTA and adequate concentrations of protease inhibitors as described (1). The tissue was first minced with scissors, further comminuted in a high speed blender $\left(45,000 \mathrm{rev} \cdot \mathrm{min}^{-1}\right.$ for two $10 \mathrm{sec}$ periods $)$ and then homogenized in a Teflon glass homogenizer (ten passes at 800 $\mathrm{rev} \cdot \mathrm{min}^{-1}$ during two 2 -min periods, all-round clearance $2 \%$ ). The homogenate was centrifuged at $1000 \times \mathrm{g}$ for $20 \mathrm{~min}$ and the particulate material rehomogenized and recentrifuged as before. The combined supernatants (here referred to as cytoplasmic extracts) were subjected to centrifugal density gradient separation in a zonal rotor (see below).

From electric organ. The collagenous nature of the tissue required a more vigorous technique and utilized a modification $(5,12)$ of our original method $(18)$. Briefly, the tissue $(70-80 \mathrm{~g})$ was frozen in liquid nitrogen, crushed to a coarse powder, and after warming to $-10^{\circ} \mathrm{C}$, suspended in $0.935 \mathrm{M} \mathrm{NaCl}$ in a tissue to salıne ratio of 18.1 The slurry was squeezed through cheesecloth to remove large fragments of tissue and then centrifuged at $10,000 \mathrm{rev} \cdot \mathrm{min}^{-1}$ for $30 \mathrm{~min}$ to remove smaller fragments. The supernatant cytoplasmic extract was further fractionated by density gradient centrifuging (see below)
TABLE 1

GRP IMMUNOREACTIVITY IN TORPEDO AND GUINEA PIG TISSUES

\begin{tabular}{lc}
\hline Tissue & $\begin{array}{c}\text { GRP Immunoreactivity* } \\
\text { (ng.g }{ }^{-1} \text { of tissue) }\end{array}$ \\
\hline Whole intestine & $986 \pm 128$ \\
Electric lobe & $404 \pm 63$ \\
Electromotor nerves & $060 \pm 022$ \\
Electric organ & $186 \pm 036$ \\
Guinea pig MPLM & $248 \pm 40$
\end{tabular}

*Values are means of four experiments \pm SD and are expressed as porcine GRP equivalents

Other tissues. Torpedo gut, electric lobes and electromotor nerves were dissected from anaesthetızed fish and immediately frozen in liquid $\mathrm{N}_{2}$. Frozen tissues were stored at $-80^{\circ} \mathrm{C}$ until crushing and extraction.

\section{Density Gradient Centrifuging}

The basic procedure was a modification $(1,5,12)$ of our orıgınal method (18). Briefly, gradients are formed in a Beckman gradient maker from two solutions of sucrose- $\mathrm{NaCl}$ in proportions determined by the profile of a control cam. At a suitable point the denser of these two solutions is replaced by an even denser one, thereby generating a smooth density gradient with two inflexions in it. The gradient is formed horizontally in a $300-\mathrm{ml}$ Beckman T1-60 zonal rotor while the rotor is spinning and is held back from the outer wall of the rotor by a cushion of dense $(1.6 \mathrm{M})$ sucrose

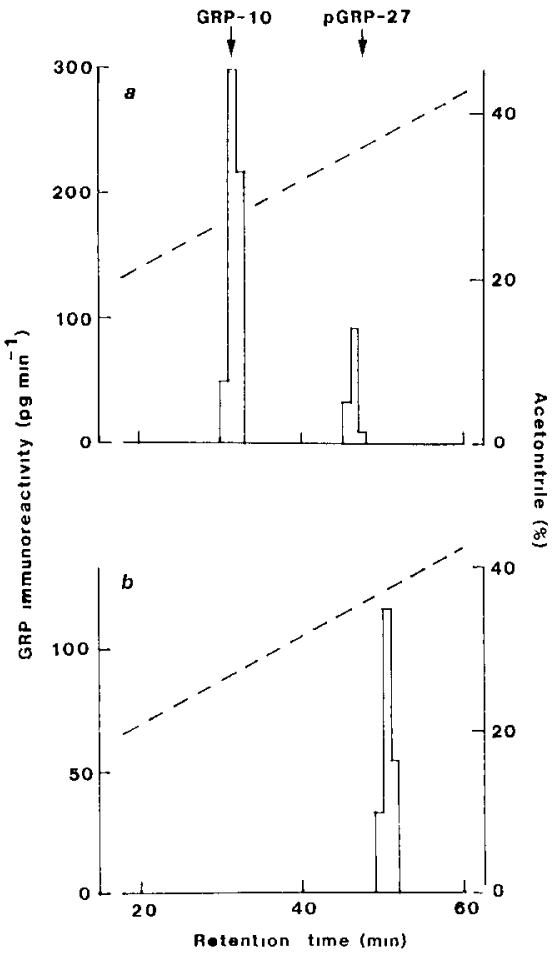

FIG 2 Reversed phase HPLC of acid extracts of (a) guinea p1g MPLM and (b) Torpedo electric organ The arrows indicate the retention times of pGRP-10 and GRP-27 The volumes of extract chromatographed corresponded to about $40 \mathrm{mg}$ of tissue 


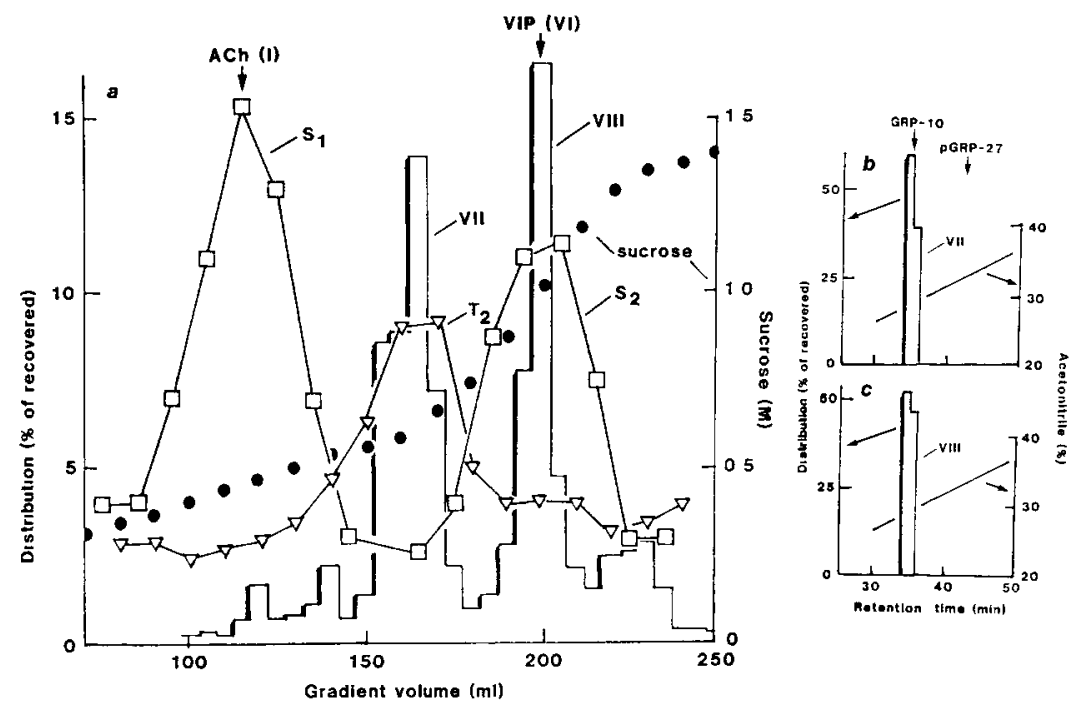

FIG 3 (a) Distribution of GRP immunoreactivity (blocks), the vesıcle marker synaptophysin (squares) and the Golgi marker thiamıne triphosphatase (inverted triangles) in a sucrose density gradient after centrifugal separation of a MPLM extract in a zonal rotor GRP immunoreactivity is found mainly in two peaks, designated, in extension of our previous terminology (2), VII and VIII Peak VII coincides with a peak $\left(T_{2}\right)$ of the Golgi marker and peak VIII with a second peak $\left(\mathrm{S}_{2}\right)$ of the vesicle marker synaptophysin and peak VI of VIP (arrow). Negligible GRP immunoreactivity is found in a region of the gradient where acetylcholıne $(\mathrm{ACh})$-nch synaptic vesicles congregate (arrow), here marked by the first peak $\left(S_{1}\right)$ of synaptophysin $(b, c)$ Behavior, on HPLC, of GRP immunoreactivity from (b) peak VII, (c) peak VIII, Identıfyıng these as being due to GRP-10

The addition of the sample of tissue extract and an overlay of the homogenization medium completes the gradient. Centrifuging is for $3 \mathrm{hr}$ at $60,000 \mathrm{rev} \cdot \mathrm{min}^{-1}$ after which the gradient is pumped out and collected in 5-ml fractions.

The gradient for work with extracts of MPLM utilized $032 \mathrm{M}$ sucrose as the light solution, and $0.6 \mathrm{M}$ sucrose as the dense solution; this was replaced, after $200 \mathrm{ml}$ of gradient had been delivered, by $1.4 \mathrm{M}$ sucrose. The volume of sample was $40 \mathrm{ml}$ derived from 8-10 $\mathrm{g}$ of tissue.

For extracts of electric organ a more sharply inflected gradient was used. The light solution was $0.2 \mathrm{M}$ sucrose- $0.311 \mathrm{M} \mathrm{NaCl}$, the first dense solution was $1.2 \mathrm{M}$ and the second $1.6 \mathrm{M}$ sucrose, the switch was after $100 \mathrm{ml}$ of gradient had been delivered. The sample volume was $30 \mathrm{ml}$ corresponding to $54 \mathrm{~g}$ of electric organ. The higher osmolarity of the light solution compared to that used with MPLM preparations is dictated by the high (ca. $800 \mathrm{mOsM}$ ) osmolarity of the Torpedo's body fluids.

\section{Analytical Techniques}

GRP Immunoreactivity. GRP was measured in crushed frozen tissues, tissue extracts, zonal fractions and column effluents by a C-terminal-specific radioimmunoassay as previously described (14) using synthetic porcine GRP as a standard. The antiserum used (14) showed equimolar cross-reactivity with porcine GRP-10 and -27 , neuromedın $C$ and amphibian bombesin but none at 1000-fold molar excess with other peptides including VIP, PHI, NMU, SP, NKA, NPK or NKB. Cross-reactivity with neuromedin B was $1 \%$. To extract the neuropeptide from tissues, they were stirred at $4^{\circ} \mathrm{C}$ for $12-15 \mathrm{hr}$ with 10 volumes of an ethanol- $0.7 \mathrm{M}$ $\mathrm{HCl}$ mixture, 3:1 v/v; particulate material was removed by centrifuging at $1600 \times \mathrm{g}$ for $30 \mathrm{~min}$ and the supernatants lyophilized. The advantage of adding ethanol to the acidic extractant

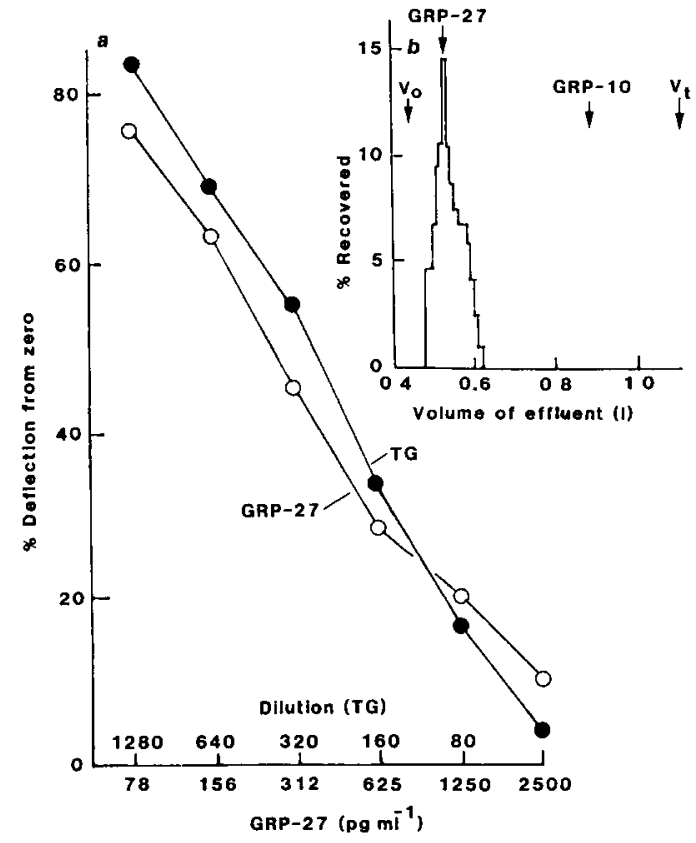

FIG 4 (a) Displacement curves of Torpedo gut GRP immunoreactivity (filled circles, TG) and authentic porcine GRP-27 (open circles) (b) Gel permeation chromatography of gut GRP immunoreactıvity, which is seen to have the same retention volume as authentic porcine GRP-27 Arrows $\left(\mathrm{V}_{\mathrm{o}}\right)$ vold volume of column, $\left(\mathrm{V}_{\mathrm{t}}\right)$ occluded volume, (GRP-27, GRP-10) retention volumes of GRP-27 and GRP-10, respectively 


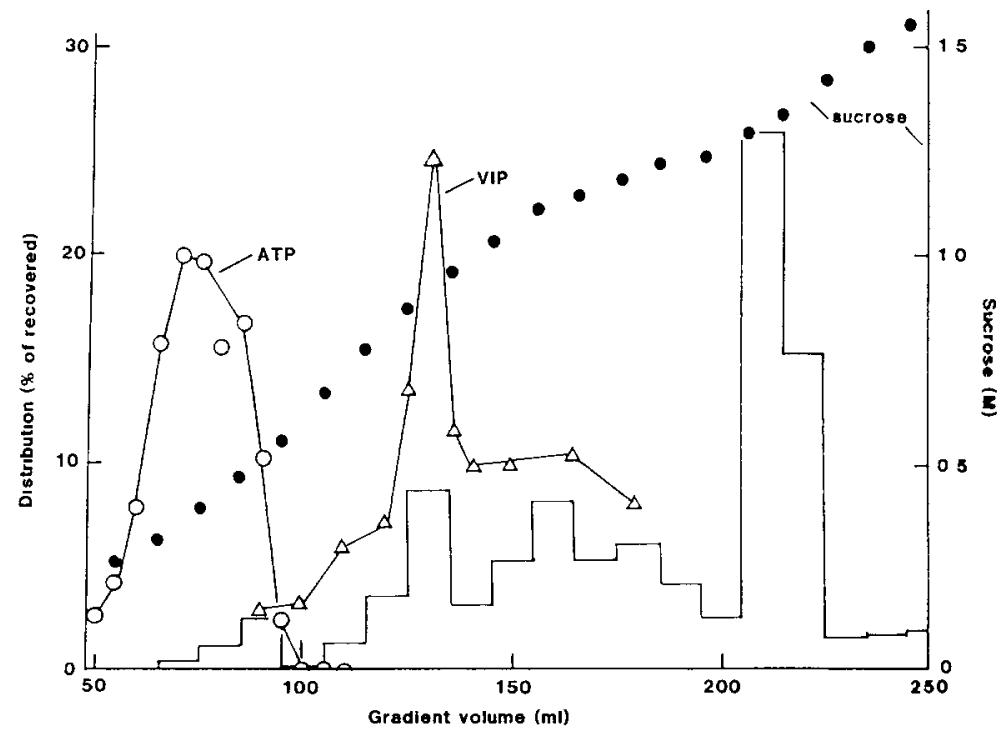

FIG 5 Distribution of GRP immunoreactivity (blocks) and synaptic vesicle-bound ATP (open circles) in a sucrose density gradient after centrifugal separation of a cytoplasmic extract of Torpedo electric organ in a zonal rotor The distribution of VIP-like immunoreactivity (triangles, VIP) is also shown

is that many high molecular mass proteins which interfere with the radioımmunoassay are removed (C. Shaw, unpublished observatıons) Samples of density gradıent fractions were brought to $95^{\circ} \mathrm{C}$ by the addition of 10 volumes of bolling distilled water, maintained at that temperature for $5 \mathrm{~min}$ in a bolling water bath, chilled on ice and treated with acetic acid to a final concentration of 01 $\mathrm{M}$. They were then lyophilized and stored at $-20^{\circ} \mathrm{C}$ t1ll assayed

Chromatography. Gel permeation chromatography of extracts ( $1 \mathrm{ml}$ ) was performed using a $90 \times 1.6 \mathrm{~cm}$ column of Sephadex G-50 (superfine; Pharmacia, Uppsala, Sweden) equilibrated in 1 $\mathrm{M}$ acetic acid at $4^{\circ} \mathrm{C}$ and eluted at a flow rate of $10 \mathrm{ml} \cdot \mathrm{hr}^{-1}$ Fractions $(2 \mathrm{ml})$ were collected and the column was calıbrated with blue dextran $\left(\mathrm{V}_{\mathrm{o}}\right)$, porcine GRP-27 and GRP-10, and potassium dichromate $\left(V_{t}\right)$. Immunoreactive fractions were subjected to reverse phase high performance liquid chromatography (HPLC) analysis using a Supelcosil LC-18-DB column $(25 \times 046 \mathrm{~cm})$ (Supelco, Bellafonte, PA) equilibrated in $01 \%$ aqueous trifluoroacetic acid and eluted with a gradient from 10 to $425 \%$ acetonitrile in $01 \%$ aqueous trifluoroacetic acid in $60 \mathrm{~min}$. The flow rate was $1.5 \mathrm{ml} \cdot \mathrm{min}^{-1}$ and the fraction volume $1.5 \mathrm{ml}$ Recoveries of GRP immunoreactivity after chromatography were over $90 \%$

Synaptophysin. This putative synaptic vesicle marker (19), also known as p38 (10), has recently been shown to also be present in neuropeptide-containing particles from MPLM (1) and Torpedo electric organ (5) It was assayed by a dot-blot technique as described $(1,3,5)$.

Thiamine pyrophosphatase. This Golg1 membrane marker was measured by an adaptation (5) of a histochemical method (11).

\section{RESULTS}

\section{MPLM Extracts}

Chromatographic characterization of GRP immunoreactivity. Acıd-ethanol extracts of guinea pıg MPLM contained about $25 \mathrm{ng}$ porcine GRP equivalents (Table 1). When extracts were submitted to gel permeation chromatography, the immunoreactivity was resolved into two immunoreactive species coeluting with porcine
GRP-27 and GRP-10, respectively (Fig 1a). The latter form was the most abundant (about 5·1). Reverse phase HPLC (Fig 2a) also separated two immunoreactive peptides coeluting with porcine GRP-27 and GRP-10 in approximately the same ratio.

Characterization of storage particles containing GRP immunoreactivity Figure 3 shows the effect of separating a cytoplasmic extract of MPLM by density gradient centrifuging in a zonal rotor GRP immunoreactivity is bimodally distributed (Fig. 3a) The lightest peak, designated peak VII in extension of our previous terminology (2), coincides with a peak of the Golgi marker, thımıne pyrophosphatase. A denser peak (VIII) coincides with a peak of the storage vesicle marker, synaptophysin; another lighter peak of this marker coincides with a peak of ACh-rich synaptic vesicles (peak I, arrow). Peak VIII occurs in the same density range of the gradient known from earlier work (2) to contain peaks of substance P, somatostatin and VIP (in order of increasing density). A small peak or shoulder in the densest region of the gradient where synaptosomes and other larger tissue fractions accumulate is also seen

The immunoreactive material in peaks VII and VIII was submitted to HPLC Radıoimmune assay of the effluents showed that the form of GRP present was exclusively GRP-10 (Fig 3b,c).

\section{The Electromotor System of Torpedo}

Chromatographic characterization of GRP immunoreactivity Of the vanous Torpedo tissues assayed, the gut had the highest level of GRP 1mmunoreactıvity, about $100 \mathrm{ng} \mathrm{g}^{-1}$ (Table 1). Gel permeation chromatography of gut extracts revealed only one GRP Immunoreactive peak with a retention volume identical to that of porcine GRP-27 (Fig. 4b). The displacement curve of the Torpedo gut immunoreactivity is also almost identical to that of porcine GRP-27 (Fig 4a).

Relatively high levels of GRP immunoreactivity were also present (Table 1) in electric lobes, the portion of the Torpedo brain containing the cell bodies of the electromotor neurones innervatıng the electric organ. These comprise about half the mass of the lobes Lesser amounts of GRP immunoreactivity are present in the 
electromotor nerves and in electric organ where the immunoreactivity is probably accounted for by the nerve terminals.

Gel permeation chromatography of electric organ extracts again revealed, as in Torpedo gut, only one GRP immunoreactive species with a retention volume identical to that of porcine GRP-27 (Fig. 4b). In reverse phase HPLC too, only one form was detected, this time with a retention time a little longer than porcine GRP-27. Thus, there may be a slight difference between Torpedo electric organ and porcine GRP-27

Partial characterization of storage particles. The distribution of GRP immunoreactıvity in density gradients following centrifugal separation in a zonal rotor (Fig. 5) was more diffuse than previously observed for ACh or VIP-lıke immunoreactıvity; a broad peak overlapping the much sharper peak of VIP-like Immunoreactivity and a sharper peak considerably more dense than that of VIP-like immunoreactivity.

\section{DISCUSSION}

\section{Extraction Procedures}

The extraction procedure for GRP differed from the conventional one in that ethanol acidified with $\mathrm{HCl}$ was substituted for aqueous acetic acid. This has the advantage of removing proteins of large molecular masses that might otherwise interfere with the subsequent radioimmunoassay and has been thoroughly tested out (C Shaw, unpublished) The GRP content of the myenteric plexus, when extraction was performed in this way (Table 1 , line 5), 1s, however, very close to that found by Hutchison et al. (9) using the acetic acid extraction procedure

\section{Storage in MPLM}

Studies during the past few years have shown that neuropeptıdes, like other physiologically active cell components (e.g , adrenalıne, insulin), are packaged withın the cells which secrete them in storage granules of varying size and density. A knowledge of such storage particles is essential for an understanding of the release process and of the posttranslational modification of the neuropeptide secreted.

The separation and characterızatıon of peptıde storage particles has been facilitated by the use of high resolution centrifugal density gradient separation in a zonal rotor $(2,8,18)$ and also by the discovery of stable "marker" substances present in the limitıng membrane of the storage granule $(1,5)$. One of these is synaptophysın, a 38,000-Da intrinsic membrane protein $(10,19)$ present in synaptıc vesıcles, but also other, neuropeptide-storing granules $(1,5)$. Use has been made of this and also of the Golg1 membrane marker thiamine pyrophosphatase to localıze mature and immature, Golgi-associated storage partıcles in sucrose density gradients after centrifugal separation.

Fractionation of cytoplasmic extracts of MPLM in this way led to the identification of two peaks (VII and VIII) of GRP immunoreactivity in the density gradient, one of which (VII) was thiamıne pyrophosphatase positive and the other of which (VIII) was synaptophysin positive. We tentatıvely conclude that peak VII contains immature storage particles associated with Golgi membranes which have not acquired synaptophysin, whereas peak VIII consists of mature storage particles with a normal content of storage particle membrane synaptophysin Both peaks contained only GRP-10 GRP-27 was present only as a minor component associated with very dense particulate material of uncertain provenance. Further work will be required to establısh whether the particles in peak VII are the actual precursors of those in peak VIII or whether GRP-10 is repackaged after synthesis

\section{Storage in Electromotor Neurons}

Hitherto only VIP (2) and its accompanying product of posttranslational modification, PHI (6), have been found in the cholinergic electromotor neurone, both are packaged (in equimolar amounts) in a synaptophysin-positive dense storage particle (6) We have now found a second, unrelated peptide, immunochemscally and chromatographically almost identical to poreine GRP-27 in the axons of such neurones and also in the electric lobes and electric organ, regions where the cell bodies and nerve termınals of these neurones are respectively concentrated. As such terminals account for only $1-2 \%$ of the electric organ, the concentration of GRP immunoreactivity there could be quite high-even higher than in the lobe

The density gradient and chromatographic behavior of the GRP-like immunoreactıvity in cytoplasmic extracts of electric organs indicated that the peptide is stored in particulate material in this model cholinergic neurone as in those of the MPLM However, the storage particles appear to be more heterogeneous than those storing VIP.

\section{ACKNOWLEDGEMENTS}

Some of the GRP assays were performed by $\mathrm{C} S$ in the Klınısche Arbeitsgruppe fur gastrointestınale Endokrınologie der Max-Planck-Gesellschaft (Leiter, Dr J M Conlon) We are grateful to $\mathrm{Mr} \mathrm{G} \mathrm{H} \mathrm{C}$ Dowe for performing the zonal density gradient separations D V A was supported by a grant from the Deutsche Forschungsgemenschaft (Wh $1 / 4-2)$

\section{REFERENCES}

1 Agoston, $\mathrm{D} V$, Whittaker, $\mathrm{V} P$ The characterizatıon, by size, densıty, osmotic fragilıty and immunoaffinity, of acetylcholıne- and vasoactıve intestınal polypeptıde-containıng storage partıcles from myenteric neurones of the guinea pig J Neurochem. 52 1474-1480, 1989

2 Agoston, D. V , Ballmann, M , Conlon, J. M , Dowe, G H C, Whittaker, V P Isolation of neuropeptide-containing vesicles from the guinea pig lleum J Neurochem 45 398-406, 1985

3 Agoston, D V, Dowe, G H. C , Fiedler, W, Giompres, P E, Roed, I S , Walker, J H , Whittaker, V P, Yamaguchı, T A kınetıc study of stımulus-induced vesicle recycling in electromotor nerve terminals using labile and stable vesicle markers J Neurochem $471584-1592,1986$

4 Agoston, D V , Conlon, J. M., Whittaker, V P. Selective depletion of the acetylcholine and VIP of the guinea-pıg myenteric plexus by differential mobilization of distınct transmitter pools Exp Brain Res $72535-542,1988$
5 Agoston, D V, Dowe, G H C, Whittaker, V P Isolation and characterization of secretory granules storing a vasoactıve intestınal polypeptide-lıke peptide in Torpedo cholinergic electromotor neurons J Neurochem 52 1729-1742, 1989

6 Agoston, D V, Fahrenkrug, J , Mikkelsen, J D, Whittaker, V P A peptide with $\mathrm{N}$-terminal histıdine and C-terminal isoleucine amide (PHI) and vasoactive intestınal peptide (VIP) are copackaged in myenteric neurones of the guinea pig ıleum Peptıdes 10 571-573, 1989

7 Anastası, A, Erspamer, V, Buccı, M Isolation and structure of bombesın and alytesın, two analogous actıve peptıdes from the skin of the European amphibians Bombina and Alytes Experientia 27 166167,1971

8 Dowe, G H C , Kilbinger, $\mathrm{H}$, Whittaker, $\mathrm{V} P$ Isolation of cholınergic synaptic vesicles from the myenteric plexus of guınea-pig small intestine J Neurochem 35 993-1003, 1980

9 Hutchison, J B , Dimalıne, R, Dockray, G J Neuropeptides in the 
gut quantıfication and characterizatıon of cholecystokının octapeptide-, bombesin- and vasoactıve intestinal polypeptıde-like immunoreactivities in the myenteric plexus of the guinea-pig small intestine Peptides 2:23-30, 1981.

10 Jahn, R , Schiebler, W., Ouımet, C , Greengard, P A 38,000-dalton membrane protein (p38) present in synaptic vesicles Proc Natl Acad Sci USA 82 4137-4141, 1985

11 Johansson, O. Localızation of vasoactıve intestınal polypeptıde- and avıan pancreatic polypeptide-like immunoreactivity in the Golg1 apparatus of peripheral neurons Brain Res $26271-78,1983$

12 Ohsawa, K, Dowe, G H. C, Morris, S. J, Whittaker, V P The lipıd and protein content of cholinergic synaptic vesicles from the electric organ of Torpedo marmorata punfied to constant composition implications for vesicle structure Brain Res 161 447-457, 1979

13 Paton, W D M., Zar, M A The origin of acetylcholine released from guinea-pig intestıne and longıtudınal muscle strips J Physıl (Lond ) 194.13-33, 1968
14 Shaw, C, Thım, L., Conlon, J M Primary structure and tissue distribution of guinea pig gastrin-releasing peptide J Neurochem $491348-1354,1987$

15 Sheridan, N M, Whittaker, V P, Israel, M The subcellular fractionation of the electric organ of Torpedo $\mathrm{Z}$ Zellforsch 74 291-307, 1966

16 Spındel, E Mammalıan bombesın-lıke peptıdes Trends Neuroseı $9130-133,1986$

17 Tache, Y, Melchiorı, P, Negn, L, eds Bombesın-lıke peptıdes in health and disease vol 547 New York Academy of Science, 1988

18 Whittaker, V P, Essman, W. B , Dowe, G H C The isolation of pure cholinergic synaptic vesicles from the electric organs of elasmobranch fish of the family Torpedintdae Biochem J $128833-845$, 1972

19 Wiedenmann, B , Franke, W W Identification and localization of an integral membrane glycoprotein of $\mathrm{Mr} 38,000$ (synaptophysin) characterıstic of presynaptic vesicles Cell 41 1017-1028, 1985 